\title{
Food consumption by bathyal decapod crustacean assemblages in the western Mediterranean: predatory impact of megafauna and the food consumption - food supply balance in a deep-water food web
}

\author{
Joan E. Cartes ${ }^{1,2, *}$, Francesc Maynou ${ }^{1}$ \\ ${ }^{1}$ Institut de Ciències del Mar, CSIC, Pg. Joan de Borbó s/n, E-08039 Barcelona, Spain \\ ${ }^{2}$ Institut Mediterrani d'Estudis Avançats, Crta. de Valldemossa km 7,5, E-07071 Palma de Mallorca, Spain
}

\begin{abstract}
Estimates of the daily ration consumed by decapod assemblages were obtained from 2 continuous sampling cycles conducted over the middle and lower slope $(610-710 \mathrm{~m}$ and $1178-1240 \mathrm{~m}$ depth respectively) of the Catalan Sea (NW Mediterranean). Annual food consumption by decapods decreased from $82.2 \mathrm{mg}$ dry weight (DW) $\mathrm{m}^{-2} \mathrm{yr}^{-1}$ on the middle slope to $20.4 \mathrm{mg} \mathrm{DW} \mathrm{m} \mathrm{m}^{-2} \mathrm{yr}^{-1}$ on the lower slope. Additionally, from literature sources, the food consumption by fishes and the secondary production of macrobenthos and macroplankton were assessed for our deep-sea area. Combining the food consumption of megafauna (decapod crustaceans plus fishes), a model of the food supply-food consumption balance was proposed for the middle slope, the only depth stratum for which adequate information exists. On the middle slope, annual food consumption by megafauna amounted to $160 \mathrm{mg}$ DW $\mathrm{m}^{-2} \mathrm{yr}^{-1}$ while secondary production by the dominant macrobenthic taxa (suprabenthos, epibenthos and infauna) was estimated at $150 \mathrm{mg} \mathrm{DW} \mathrm{m}^{-2} \mathrm{yr}^{-1}$. Benthos was the main contributor to the food supply in our megafaunal mid-slope communities. The mean annual contribution of macroplankton was secondary, although it can be seasonally important. Euphausiids were the dominant macroplankton taxon over the middle slope, and only $10.6 \%$ of their secondary production $\left(7.3 \mathrm{mg} \mathrm{DW} \mathrm{m}{ }^{-2} \mathrm{yr}^{-1}\right.$ ) was estimated to be consumed by decapods, whereas the total estimated euphausiid production consumed by our mid-bathyal community hardly attained $20 \%$. Our results showed a tight equilibrium. between food consumption and food supply on the middle slope. Estimated food consumption by midslope megafauna $\left(0.059 \mathrm{~g} \mathrm{C} \mathrm{m}^{-2} \mathrm{yr}^{-1}\right)$ is equivalent to calculated values for production by benthic and suprabenthic macrofauna. This value is also consistent with estimates of mid-slope organic carbon through sedimentation $\left(1.8 \mathrm{~g} \mathrm{C} \mathrm{m}^{-2} \mathrm{yr}^{-1}\right.$ ), after correcting for metabolism by benthos (from macrofauna to sediment bacteria). These results are consistent with the commonly accepted idea that food is the main limiting factor in deep-sea trophic webs
\end{abstract}

KEY WORDS: Daily ration Food consumption Food supply Secondary production - Deep-sea ecology

\section{INTRODUCTION}

The growing interest in quantifying trophic relationships in marine communities has led to the adoption of daily-ration methods to determine the amount of food consumed by marine organisms in natural conditions (Durbin et al. 1983, Worobec 1984, Macpherson 1985, Pakhomov et al. 1996. Maynou \& Cartes 1997). Other

•E-mail: jcartes@icm.csic.es authors have followed this approach to estimate the food consumed by dominant characteristic species, usually target species in mono-specific fisheries (Yang \& Livingston 1988, Bulman \& Koslow 1992), or even to estimate the food required by a whole taxocenosis (Clarke 1978, Naumov 1985, Pakhomov et al. 1996, Pakhomov 1997). Fish are the main target group in these studies, as they are the dominant megabenthic taxon in most marine communities, particularly in deep-water communities (May \& Blaber 1989, Berg- 
stad 1990, Gordon \& Mauchline 1990). The results derived from these studies are of interest in trophic ecology and in the study of energy flow through trophic webs, including topics such as the contribution of the benthic and planktonic compartments to maintaining demersal trophic chains, or the predation pressure on key prey species in particular ecosystems (e.g. Euphausia superba in Antarctic waters; Pakhomov et al. 1996, Pakhomov 1997).

The quantitative relationship between the food consumed by marine fishes, the major consumers at the top level of trophic chains, and the availability of food produced by the benthos has been established in shallow-water systems for the Atlantic Ocean (Steele 1974 Jones 1978). To this end, several authors have proposed integrated studies of biological production by macrofauna, the basis of the megafaunal diet in shelf communities (Buchanan \& Warwick 1974). The aim of such studies consists basically in establishing the relationship between primary production and secondary production, and ultimately in linking the latter to fish stock (Mills 1975, Rosenberg et al. 1977, Petersen \& Curtis 1980). Most of these studies have focused on the continental shelf, where the interest in commercially exploited species justifies the study of energy flow dynamics. On the other hand, there is a notable lack of studies addressing the highest levels of trophic webs and linking food consumption to food supply, i.e. secondary production derived from prey exploited by fish (Pakhomov 1997). These kinds of studies are non-existent for deep-water bathyal or abyssal depths, despite the general consideration that food availability is the main limiting factor in deep-sea environments (Gage \& Tyler 1991). While there are practically no quantitative studies on production at bathyal and abyssal depths, food-consumption studies are limited to some upperslope environments (Macpherson 1985, Bulman \& Koslow 1992), as well as some mid-water communities (Pakhomov et al. 1996).

Although the density of deep-sea organisms tends to decrease with depth (Rowe 1983, Haedrich \& Merret 1992), the fact that deep-sea areas cover most of the globe suggests that an important part of energy flow and carbon biomass moves through deep-sea food webs (Haedrich \& Merret 1992). Estimates of the food required by deep-water organisms can be a source of information on the carrying capacity of deep environments for sustaining given levels of abundance, biomass and diversity.

Recently we applied daily ration models to the deepwater shrimp Aristeus antennatus (Maynou \& Cartes 1997), a widely dominant decapod crustacean in the middle-and lower-slope megabenthic communities in the Catalan Sea (NW Mediterranean; Cartes \& Sardà 1992, Cartes et al. 1994a). This is now a relatively well documented area, where both studies on the depth distribution of megabenthic biomass (Cartes \& Sardà 1992. Stefanescu et al. 1993) and detailed studies on dietary preferences of the dominant decapod species (Cartes 1998) have been undertaken. Fish and decapod crustaceans represent most of the biomass in bathyal Mediterranean communities, while other groups such as cephalopods or echinoderms are present at very low levels. Several decapod crustaceans are target species of commercial fisheries in the deep western Mediterranean, especially the deep-sea shrimps A. antennatus and Aristaeomorpha foliacea (Bas et al. 1985). For the study of the dynamics of food resources exploited by the megafauna, data on the biology and ecology of vagile macrofauna (suprabenthos) have recently been published (Cartes \& Sorbe 1996) and some initial data on the secondary production of characteristic species have already been obtained (Cartes \& Sorbe unpubl.). In this context, the objectives of the present work are: (1) to estimate the food consumed by, and the predatory impact of, the entire megafaunal community, particularly the decapod crustacean assemblages, and (2) using data on macrofaunal production, to establish a first estimate of the balance between food consumption and food supply over the middle-slope level, the depth stratum for which the most complete information exists.

\section{MATERIAL AND METHODS}

Decapod crustaceans: data source and estimation of daily ration. Two continuous samplings were performed in the Catalan Sea (NW Mediterranean) over the middle slope (cruise $\mathrm{DN}-1$ ) and the lower slope (cruise BT-1). During DN-1, 5 trawls were carried out in the vicinity of $41^{\circ} 07^{\prime} \mathrm{N}, 02^{\circ} 03^{\prime} \mathrm{E}$, at depths between 610 and $710 \mathrm{~m}$, on red shrimp Aristeus antennatus commercial fishing grounds. Trawling comprised an $18 \mathrm{~h}$ period between $17: 30 \mathrm{~h}$ on 13 July and 11:05 h on 14 July 1989. Daily rations were calculated for 6 species of decapods in addition to $A$. antennatus (Table 1): the shrimps Pasiphaea multidentata, Acanthephyra eximia, Plesionika martia and Plesionika acanthonotus, the polychelid lobster Polycheles typhlops and the crab Geryon longipes. The daily ration for the dominant species $A$. antenatus has been published recently (Maynou \& Cartes 1997). All these species represented $97.7 \%$ (in biomass) of the total decapod assemblage at those depths, based on the catch data of the 5 trawls (see Table 2). A red shrimp commercial trawl was used in this sampling (trawled area: $116080 \mathrm{~m}^{2} \mathrm{~h}^{-1}$; opening between wings: $25 \mathrm{~m}$; values estimated with the aid of the acoustic monitoring system SCANMAR at a towing speed of 2.6 knots). A detailed description of station 
data is available in Maynou \& Cartes (1997). Table 1 summarizes the basic sampling data for each species studied.

The BT-1 sampling cycle was performed at $41^{\circ} 00^{\prime} \mathrm{N}$, $02^{\circ} 15^{\prime} \mathrm{E}$, from 1178 to $1240 \mathrm{~m}$ depth. Nine trawls were carried out between 08:50 h on 17 March and 02:37 h on 19 March 1994 (41 h period). The duration of hauls was always $1 \mathrm{~h}$, while time between effective hauls varied between $2 \mathrm{~h} 10 \mathrm{~min}$ and $4 \mathrm{~h} 40 \mathrm{~min}$. The sampling was carried out with a MTS bottom trawl (Cartes et al. 1994a) and a 1-bridle bottom trawl (trawled area. $65005 \mathrm{~m}^{2} \mathrm{~h}^{-1}$; opening between wings: $14 \mathrm{~m}$ ) specially designed for deep-sea sampling, at a towing speed of 2.6 knots. Diet composition (\%F, frequency of occurrence) and daily ration were computed for the 3 dominant species of decapods on the lower slope (Table 1), the shrimps Acanthephyra eximia and Pontophilus norvegicus and the anomuran crab Munida tenuimana. These species, together with Aristeus antennatus and Geryon longipes, represented $97.0 \%$ of the total decapod assemblage (in biomass) at those depths (Table 2). To estimate the food consumed by decapod assemblages in the 1178 to $1240 \mathrm{~m}$ depth range, the daily ration calculated for $A$ antennatus and $G$. longipes from cruise $\mathrm{DN}-1$ was also considered in this case.

In summary, a total of 885 and 531 individuals were studied and dissected during the DN-1 and BT-1 cruises respectively. Carapace length (CL) and wet weight of individuals were measured on board. The size spectra for the major portion of decapods collected varied between 16.0 and $47.0 \mathrm{~mm}$ C.L (Table 1 ). In the laboratory, stomachs were removed and the stomach content dry weight obtained after drying in the oven at $100^{\circ} \mathrm{C}$ for $24 \mathrm{~h}$. The stomach fullness index is expressed as g dry weight food per $100 \mathrm{~g}$ predator wet weight ( $\%$ DW/WW).

Before drying, the diet composition was analyzed in detail for each species. Complete results for DN-1 species have already been published in Cartes (1993), while data for the lower-slope stratum are also included in the present paper. Seventy individuals of Acanthephyra eximia, 37 of Pontophilus norvegicus, and 139 of Munida tenumana were examined for dietary studies, and \%F calculated for the main prey taxa. We classified stomach contents in the following 5 categories, based on their predominance in the foreguts of food of different origin: pelagic (macroplankton), benthic and suprabenthic (i.e. non-mobile and vagile macrofauna, respectively, retained in a mesh size of $500 \mu \mathrm{m})$, megafaunal remains and unidentified items. Usually one of these categories dominated by weight in the foregut and it was relatively easy to directly assign the weight of the stomach contents to one of the 5 groups established. The only exception was Aristeus antennatus, a species with a very high trophic diversity and a high number of prey of different origin in each stomach. The prey often appear broken and mixed (Cartes 1994). To allocate the weight of the stomach contents in this species, the estimated volume (in fresh stomachs) occupied by each prey was distributed according to the subjective points method (Swynnerton \& Worthington 1940). This method assigns a number of points $(100,75$, etc. $)$ according to the relative volume occupied by each prey item in a foregut. The volume occupied by each prey item in the contents is visually estimated under a stereomicroscope (10x to $40 x$ ), and according to their dominance a number of points is assigned to each prey category. Thus, we obtained a sum of points and a percentage of estimated

Table 1. Sampling data on dominant decapods in bathyal assemblages on the middle and lower slope of the Catalan Sea (NW Mediterranean) for food consumption estmates. $\mathrm{n}(\max -\min )$ is the number of individuals analysed for each species, specifying the maximum and minimum number in each sample. $\mathrm{CL}$ : carapace length; $\mathrm{N}$ : number of samples in which the species were present

\begin{tabular}{|c|c|c|c|c|c|}
\hline Species & $\mathrm{n}(\max -\min )$ & $\begin{array}{l}\text { Size range } \\
(\mathrm{CL}, \mathrm{mm})\end{array}$ & $\begin{array}{l}\text { Mean size (min-max) } \\
\text { (CL, mm) }\end{array}$ & $\begin{array}{l}\text { Sampled time } \\
\text { interval }(\mathrm{h})\end{array}$ & N \\
\hline \multicolumn{6}{|l|}{ DN-1 (July 1989) } \\
\hline Aristeus antennatus ${ }^{\circ}$ & $165(36-30)$ & $17.2-59.9$ & & 18 & 5 \\
\hline Pasiphaea multidentata & $189(71-19)$ & $23.0-45.1$ & $29.2-33.9$ & 18 & 5 \\
\hline Acanthephyra eximia & $48(19-5)$ & $26.3-39.9$ & $30.2-31.9$ & 18 & 4 \\
\hline Plesionika martia & $163(54-11)$ & $16.2-26.7$ & $20.9-21.7$ & 18 & 5 \\
\hline Plesionika acanthonotus & $75(31-14)$ & $12.0-18.7$ & $14.0-14.4$ & 13 & 3 \\
\hline Polycheles typhlops & $150(56-10)$ & $16.0-44.3$ & $30.1-32.7$ & 18 & 5 \\
\hline Geryon longipes & $95(37-7)$ & $22.9-68.0$ & $54.7-59.8$ & 18 & 5 \\
\hline \multicolumn{6}{|l|}{ BT-1 (March 1994) } \\
\hline Acanthephyra eximia & $85(23-8)$ & $17.0-47.0$ & $23.9-26.2$ & 41 & 8 \\
\hline Pontophilus norvegicus & $198(38-13)$ & $4.8-1.2 .0$ & $8.6-9.7$ & 27 & 7 \\
\hline Munida tenumana & $248(57-31)$ & $5.3-22.3$ & $15.2-16.4$ & 27 & 6 \\
\hline${ }^{a}$ From Maynou \& Cartes & & & & & \\
\hline
\end{tabular}


volume for the 5 food categories established. This percentage was later applied to the total weight of the stomach contents

In a previous work, we applied 3 models for the determination of daily ration food consumption by Aristeus antennatus (Maynou \& Cartes 1997): the models of Eggers $(1977,1979)$ and Elliott \& Persson (1978). The daily ration estimates derived from these 3 models were not significantly different. In a recent work (Maynou \& Cartes 1998, this issue) we extended the analysis to 8 other species of decapod crustaceans. The daily rations estimated by the 3 models did not differ significantly in this case either, and for our multispecific approach in this study, we chose the results obtained using the Eggers (1977) model. We considered this model to be the best suited for our study because: (1) most species did not show significant feeding peaks (Maynou \& Cartes 1998, this issue), which is the basic assumption in this model; (2) according to Bosclair \& Leggett (1988), this model is recommended when using field data and when $R$ (the evacuation rate) cannot be determined experimentally, as in our case. Additionally, the application of a single model to all species eases comparison among them by standardizing the results, because the differences among models could mask the variability among species. Thus, the consumption of each species over a $24 \mathrm{~h}$ cycle is:

$$
C=F_{24} R 24
$$

where $F_{24}$ is the mean stomach fullness index over $24 \mathrm{~h}$, in \% DW/WW. This model assumes that the weight of the stomach contents does not change significantly between the beginning and the end of the

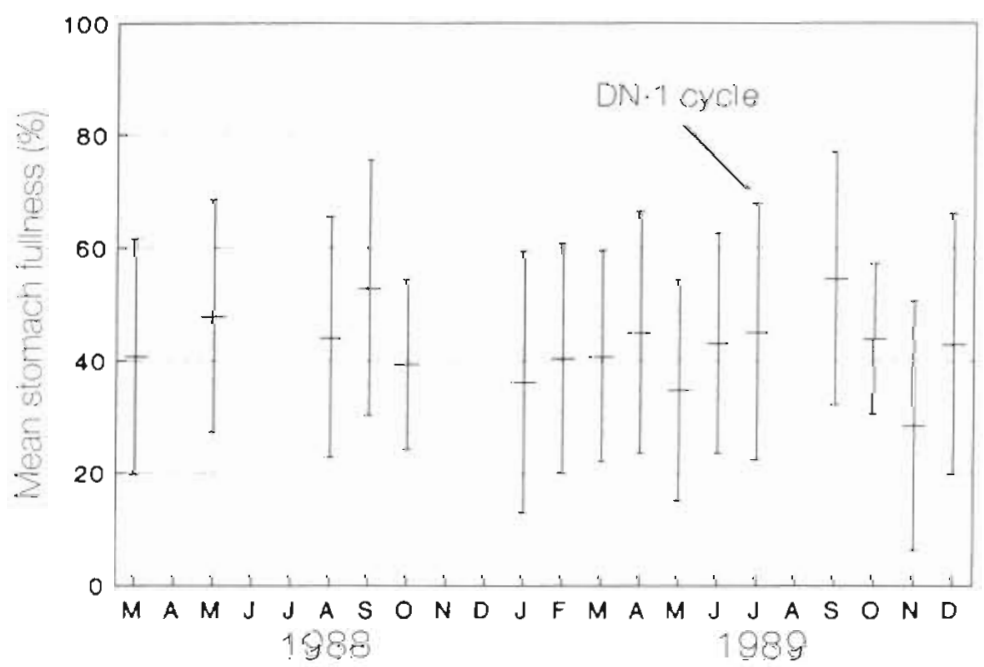

Fig. 1. Aristeus antennatus. Seasonal vanations of mean stomach fullness of shrimp on the middle slope $(570-728 \mathrm{~m}$ depth) in the studied area during March 1988 to December 1989 (2371 individuals analyzed; between 72 and 414 ind $\mathrm{mo}^{-1}$ ) study period. $R$, the gastric evacuation rate, is required for the estimation of daily ration. We adopted the experimental value of $R$ recalculated from data in Sardà \& Valladares (1990) in their study of Nephrops norvegicus performed in the laboratory at $13^{\circ} \mathrm{C}$, the same temperature as in deep-water Mediterranean environments (justified in Maynou \& Cartes 1997). Three $R$ values were computed, one for each of the different feeding guilds of the species studied (see Cartes 1998 and Maynou \& Cartes 1998 for details), basically depending on the type of food consumed by the predator species: soft, hard or mixed prey. As shown by Elliott \& Persson (1978) and Bromley (1994), the evacuation rate depends mainly on temperature and type of prey. Pasiphaea multidentata, a mesopelagic shrimp characterized by regular vertical migrations between the water column and the slope bottom (Franqueville 1971), is a problematic species due to its particular feeding behaviour and was subjected to a different analysis (Maynou \& Cartes 1998)

Determination of annual food consumption in decapod crustacean assemblages. The present study comprised 2 specific sampling cycles performed at $650-710$ and 1178-1240 $\mathrm{m}$ depth. These depths are representative of 2 different bathyal communities regarding decapod crustaceans and megafaunal composition (Cartes \& Sardà 1993, Cartes et al. 1994a, Sardà et al. 1994). Oceanographic conditions were also different in the 2 periods sampled. While in summer ( $D N-1$ cruise) the most important oceanographic feature is the stratification of the water column, March (BT-1 cruise) coincides with a mixing period when a peak in primary production is regularly reported in the study area.

We extrapolated the results of DN-1 to an annual scale, bearing in mind that both daily ration and biomass can vary seasonally. Unfortunately, daily rations for different seasons are not available, although changes in mean percentage of stomach fullness can be indicative of changes in food consumption. Aristeus antennatus, the species responsible for the largest share of the food consumed on the middle slope, due to its dominance in biomass, did not show significant changes in mean \% of fullness between DN-1 and the rest of the monthly samples in the period 1988-89 (Fig. 1). Mean fullness during DN-1 (July 1989) was $45.1 \%$, slightly higher than the yearly mean of $41.7 \%$ (deduced from data in Fig. 1). Megafaunal crustacean densities were higher in July 1992 (66.9 ind. per $10000 \mathrm{~m}^{2}$ ) than the annual average (49.3 ind. per $1.0000 \mathrm{~m}^{2}$ ) for the period 1991-1992 (Fig. 2). These data may suggest that our annual 
extrapolation from the July 1989 results slightly overestimate the annual food consumed by decapod assemblages on the middle slope.

For the lower slope, we adopted the values of daily ration obtained for Aristeus antenatus and Geryon longipes on the middle slope. We can assume this extrapolation for $A$. antennatus is adequate, considering that the temperature in Mediterranean deep waters is constant and relatively high throughout the year, $13 \pm 0.5^{\circ} \mathrm{C}$ below $200 \mathrm{~m}$ depth (Hopkins 1985). However, stomach fullness, as a primary indicator of food consumption, decreased with depth and thus was higher on the middle slope ( 1.2 times) than on the lower slope (see Cartes 1994), producing a slight overestimation when extrapolating daily ration values from the middle slope to the lower slope. On the other hand, the density values obtained in winter (March 1992) were lower than the values obtained in spring and autumn 1991 and in summer 1992 (Fig. 2), hence our data in the BT-1 cycle probably underestimate the annual predatory intensity on the lower slope. $G$. longipes is a secondary species in the lower-slope assemblage, and furthermore no appreciable changes in $\%$ of fullness or biomass were detected between 610 and $1322 \mathrm{~m}$ in a previous work (Cartes 1993).

Daily ration and annual food consumption in bathyal fish. No data on daily ration for bathyal Mediterranean fishes are available. However, studies exist on bathyal fishes for other geographical areas, such as the southeastern Atlantic off Namibia (Macpherson 1985) and the southwestern Pacific off South Australia (Bulman \& Koslow 1992, Koslow 1996), while the daily ration in mesopelagic Lampanyctus spp. has been deduced from metabolic rates (Childress et al. 1980). These studies sometimes included the same species (or similar species in the same family) as those species dominating middle-slope fish assemblages in the western Mediterranean (i.e. Macrouridae, Helicolenus dactylopterus, Lophius spp., Myctophidae). Also, some basic biological characteristics of these bathyal species, such as morphology and diet, are close to those of dominant fish in our slope area (see data sources cited in Table 4). Furthermore, other species such as Hoplostethus atlanticus seem to have a food niche similar to that of our benthopelagic species, such as the blue whiting gadid Micromesistius poutassou. We obtained a rough estimate of daily ration for our fish assemblages by multiplying a mean value of daily ration deduced from 7 bathyal species from other areas (see Table 4) by estimates of mean annual biomass for fish assemblages in our study area (Cartes et al. 1994 a Sardà et al. 1994). We obtained values of fish biomass from 2 different samplings (RETRO and GEOS cruises) during both 1991 and 1992. In the RETRO cruise a fixed station was sampled in each season of the year

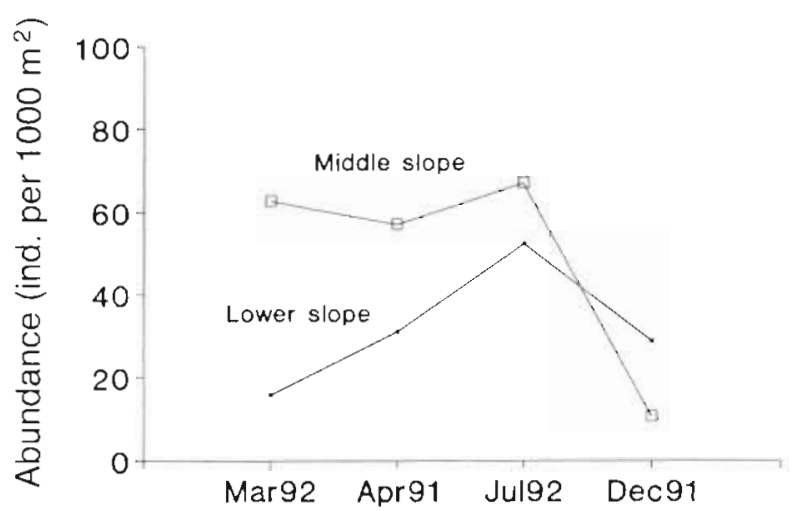

Fig. 2. Seasonal changes in decapod crustacean adundance at the middle slope and the lower slope in the studied area during the period April 1991 to July 1992

(12 trawls carried out between 545 and $692 \mathrm{~m}$ i see details in Sardà et al. 1994). In the GEOS cruise 13 trawls were performed in an area between $41^{\circ} 07^{\prime} \mathrm{N}$, $1^{\circ} 36^{\prime} \mathrm{E}$ and $41^{\circ} 14^{\prime} \mathrm{N}, 2^{\circ} 33^{\prime} \mathrm{E}$, at depths between 514 and $730 \mathrm{~m}$ (Maynou et al. 1996) off Barcelona. We followed this approach only for the middle-slope depth stratum, as our lower-slope fish assemblages have special characteristics, with species such as Alepocephalus rostratus and Bathypterois mediterraneus, whose diets are based on gelatinous plankton and copepods (Carrasson 1994), and show a biomass peak at 1000 to $1200 \mathrm{~m}$ (Stefanescu et al. 1993, 1994). These characteristics, together with the lack of information on food consumed by comparable species, preclude a sensible extrapolation like that undertaken for our middle-slope fish assemblages.

Estimating food supply: secondary production and biomass of macrofauna and macroplankton. We obtained estimates of production of the different species or taxa which dominate the benthic compartment (macrofauna) and macroplankton in the study area. We considered 3 compartments in macrofaunal communities, based on the habitat of the species and the different methods existing to sample each compartment. Thus, macroplankton was traditionally sampled with IKMT or RMT pelagic gears, epibenthic and endobenthic fauna was sampled with grabs or quantitatively with box-corers, while suprabenthos (byperbenthos or vagile macrofauna) was sampled with sledges (Cartes et al. 1994b). Euphasiids, mainly Meganyctiphanes norvegica, were selected as the most representative taxa in macroplankton communities (Franqueville 1971, Sardou et al. 1996), peracarid crustaceans as the dominant group in suprabenthic communities (authors' unpubl. data), and polychaetes as the dominant taxa among the infauna (Reyss 1971). We used wet weights (authors' unpubl. data) to calculate production for macrofauna. Although biomass val- 
ues for macrofauna are often expressed as DW or AFDW (ash-free dry weight), these methods are destructive of the samples, and in deep-sea studies the non-destructive measurement of wet weight is alternatively recommended (Gage 1992). We obtained wet weight after drying samples on blotting paper for 15 min. Both in this case and also for megafauna (fish and decapods) we applied conversion factors for converting wet weight to dry weight based on our own data. When data was not available, a standard conversion factor of 0.25 (DW/WW ratio) was applied. DW was converted to carbon equivalents using a mean conversion factor of 0.369 from results summarized in Jorgensen et al. (1991) using different benthic and plankton taxa.

Meganyctiphanes norvegica represents between 19 and $23 \%$ of the total abundance of macroplankton (Franqueville 1971, Sardou et al. 1996). This species, together with 2 smaller species, Euphausia krohni and Nematoscelis megalops, which make up $13 \%$ of the total macroplankton abundance (Sardou et al. 1996), forms the largest share of the euphausiid bathyal assemblages in our study area. Thus the contribution of euphausiids to macroplankton communities in terms of biomass must be even greater, due to their high mean individual weight $(0.09$ to $0.15 \mathrm{~g} \mathrm{WW}$ for $M$. norvegica; Franqueville 1971). P/B (production/biomass) ratios for these 3 euphausiids have been obtained by different authors in Atlantic and Mediterranean waters (Lindley 1982, Mauchline 1985, Labat \& Cuzin-Roudy 1996). P/B was 3.4 and 6.1 for $N$. megalops and E. krohni respectively in North Atlantic waters (Lindley 1982, Mauchline 1985). $\mathrm{P} / \mathrm{B}$ for $M$. norvegica was 1.24 in the northwestern Mediterranean (Labat \& Cuzin-Roudy 1996), and 1.6 in the Rockall Trough, northeastern Atlantic (Mauchline 1985).

An estimate of secondary production and $\mathrm{P} / \mathrm{B}$ for the 4 dominant peracarid species in our bathyal assemblages was obtained by applying both the Morin \& Bourassa (1992) empirical model and the HynesHamilton frequency method (Cartes \& Sorbe unpubl.). The equation of the Morin \& Bourassa (1992) model. to estimate $P$ is:

$$
\log P=-0.75+1.01 \log B-0.34 \log W+0.037 T
$$

Where $P$ is annual production; $B$ is the mean annual biomass ( $\mathrm{g} \mathrm{DW} \mathrm{m}{ }^{-2}$ ); $W$ is the mean individual weight ( $\mathrm{g}$ DW), computed as the quotient $B / D$, where $D$ is the mean annual density (ind. $\mathrm{m}^{-2}$ ); and $T$ is the temperature $\left({ }^{\circ} \mathrm{C}\right)$. Compared to other production models, Morin \& Bourassa's has the advantage of incorporating temperature. In the NW Mediterranean the temperature of the water masses below $200 \mathrm{~m}$ is nearly constant year-round $\left(13.0 \pm 0.5^{\circ} \mathrm{C}\right.$, Hopkins 1985$)$. Based on our own un.published data, we used a value of $13.1^{\circ} \mathrm{C}$ in this equation.
The most abundant peracarids in our study were the mysid Boreomysis arctica, strongly dominant in our bathyal communities (Cartes \& Sorbe 1995), the amphipods Rhachotropis caeca and Rhachotropis gabra, and the cumacean Leucon longirostris. The mean $\mathrm{P} / \mathrm{B}$ computed for those species was 8.05 and was extrapolated to the entire peracarid community. The mean $\mathrm{P} / \mathrm{B}$ value obtained with this empirical model was close to the value obtained with the HynesHamilton method (Cartes \& Sorbe unpubl.). An estimate of peracarid mean biomass (non-destructive wet weight) was obtained from 4 sampling cruises conducted between April 1991 and July 1992 (see details in Cartes et al. 1994b). This sampling covered a depth range between 389 and $1355 \mathrm{~m}$ at 4 fixed stations (upper slope, between 389 and $402 \mathrm{~m}$; canyon, between 389 and $506 \mathrm{~m}_{i}$ middle slope, between 549 and $601 \mathrm{~m}$; lower slope, between 1250 and $1355 \mathrm{~m}$ ) and 4 annual seasons (R1: April 1991; R2: December 1991; R3: March 1992; R4: July 1992). Samples were obtained with a Macer-GIROQ sledge (Cartes et al. 1994b).

Finally, no quantitative data for infaunal density and biomass is available in our study area. In studies of the biocenosis of the neighbouring Lacaze-Duthier and Cap de Creus canyons, polychaetes were largely the dominant group in this category $158 \%$ of the total macrofauna collected). Studies quantifying polychaete biomass are restricted to the continental shelf in our area (e.g. Guille 1971, to depths of $91 \mathrm{~m}$ ). We adopted values for deep-sea polychaete biomass (0.027 $\mathrm{g} \mathrm{DW}$ $\mathrm{m}^{-2}$ ) from the study of Tselepides \& Eleftheriou (1992) in the south Aegean Sea (eastern Mediterranean). Given the lack of $\mathrm{P} / \mathrm{B}$ ratios for deep-water polychaetes, we used a value of 1.83, based on a study of Brey (1990) summarizing the $\mathrm{P} / \mathrm{B}$ rations for 32 shallow-water polychaetes from subartic to temperate areas. Although it is known that production is clearly lower in deep-water suprabenthic peracarids (Cartes \& Sorbe unpubl..) and bivalves (Gage 1992) than in shallow-water species, the $\mathrm{P} / \mathrm{B}$ ratio falls in the same range for shallow and bathyal species (Cartes \& Sorbe unpubl.). Based on this finding we feel that we can reasonably extrapolate $\mathrm{P} / \mathrm{B}$ ratios from shallow-water to deep-water polychaetes, within the framework of our approach.

\section{RESULTS}

\section{Daily rations of decapods and annual food consumption}

The estimates of daily ration ( $\%$ DW/WW) for the dominant species in each depth stratum are shown in Table 2. The daily rations ranged from $1.205 \%$ 
Table 2. Daily ration (DR; \% DW/WW) and mean biomass (g WW per $10000 \mathrm{~m}^{2}$ ) of dominant decapods in bathyal assemblages on the middle and lower slope of the Catalan Sea. N: number of samples in which the species were present for mean biomass estimates p: pelagic: b: benthic

\begin{tabular}{|lccc|}
\hline Species & DR & Mean biomass & N \\
\hline DN-1, middle slope & & & \\
Aristeus antennatus & 0.223 & 771.9 & 5 \\
Pasiphaea multidentrta & $0.729(\mathrm{~b})_{1} 1.205(\mathrm{p})$ & 23.6 & 5 \\
Acanthephyra eximia & 0.435 & 10.6 & 5 \\
Plesionika martia & 0.442 & 20.4 & 5 \\
Plesionika acanthonotus & 0.323 & 9.5 & 5 \\
Polycheles typhlops & 0.096 & 30.8 & 5 \\
Geryon longipes & 0.061 & 172.1 & 5 \\
Total & & 1062.8 & \\
BT-1 lower slope & & & \\
Aristeus antennatus & & 81.2 & 10 \\
Acanthephyra eximia & 0.223 & 11.3 & 10 \\
Pontophilus norvegicus & 0.750 & 2.6 & 10 \\
Munida tenuimana & 0.680 & 28.4 & 10 \\
Geryon longipes & 0.904 & 24.7 & 10 \\
Total & 0.061 & 148.8 & \\
"From Maynou \& Cartes (1997) & & & \\
"DR data adopted from the middle-slope level & & \\
\hline
\end{tabular}

(Phrosina semilunata), and fish remains. Gelatinous remains were often associated with hyperiid remains, and perhaps are attributable to salp or gelatinous plankton. Pontophilus norvegicus based its diet mainly on polychaetes (Table 3 ). The preferred food of Munida tenuimana was euphausiids (Meganyctiphanes norvegica), fish remains and, secondarily, siphonophores (Table 3). While the major part of the diet in $A$. eximia and $M$. tenuimana was of pelagic origin, $P$. norvegicus based its diet on benthic macrofauna.

The quantitative food composition of decapods in terms of biomass is shown in Fig. 3. Benthic resources were dominant on the middle slope $(43.7 \%$ of total weight), and were constituted by (in decreasing order of importance) Calocaris macandreae,
DW/WW for the mesopelagic shrimp Pasiphaea multidentata to $0.061 \%$ DW/WW for the crab Geryon longipes, with mean values of $0.364 \%$ DW/WW on the middle slope and $0.524 \%$ DW/WW on the lower slope. Shrimps and prawns had higher daily rations than lobsters and crabs (see Maynou \& Cartes 1998, for a detailed discussion). The biomass contribution was different for each species: Aristeus antennatus dominated both over the middle slope (DN-1, July 1989; $771.9 \mathrm{~g}$ WW per $10000 \mathrm{~m}^{2}$ ) and the lower slope (BT-1, March $1994 ; 81.2 \mathrm{~g}$ WW per $10000 \mathrm{~m}^{2}$ ), while the contribution of other species was lower (Table 2). From these results, the food consumed by our decapod assemblages was estimated at 2.251 and $0.556 \mathrm{~g}$ DW per $10000 \mathrm{~m}^{2} \mathrm{~d}^{-1}$ on the middle and lower slope, respectively. These values represent an annual food consumption of $82.2 \mathrm{mg} \mathrm{DW} \mathrm{m}^{-2} \mathrm{yr}^{-1}$ on the middle slope, and $20.4 \mathrm{mg} \mathrm{DW} \mathrm{m} \mathrm{mgr}^{-1}$ on the lower slope.

\section{Dietary composition}

The diet composition of the dominant decapod megafauna has been reported on in detail for DN-1 species (Cartes 1994). Here we describe the dietary composition of the lower-slope species Acanthephyra eximia, Pontophilus norvegicus, and Munida tenuimana. The main food items occurring in stomachs of $A$. eximia were natantian decapods (Acanthephyra pelagica, Pasiphaea multidentata), gelatinous remains, hyperiid amphipods
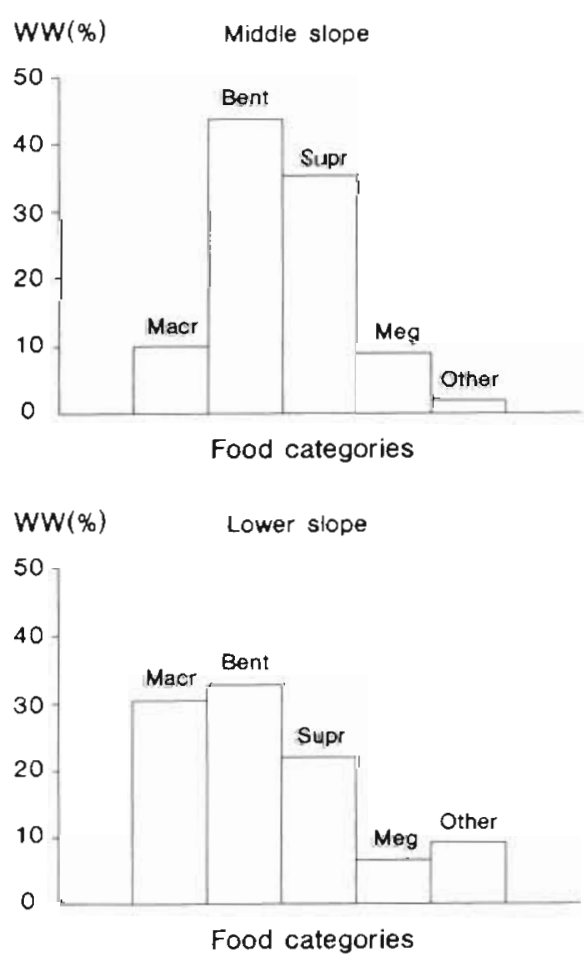

Fig. 3. Percentage contribution of the main compartments or food categories to the diet of decapod assemblages at the 2 bathymetric levels studied. Macr: macroplankton prey items; Bent: benthic macrofauna (epifauna + infauna) prey items; Supr: suprabenthos (vagile epifauna; macrofauna) prey items; Meg: megafaunal (fish + large decapods) remains; Other: mainly unidentified items 
Table 3. Acanthephyra eximia, Pontophilus norvegicus and Munida tenuimand. Composition of the diet of 3 dominant decapods on the lower slope. Values are \%F (frequency of occurrence). n: number of stomach contents analyzed

\begin{tabular}{|c|c|c|c|}
\hline Prey taxon & $\begin{array}{c}\text { A. eximia } \\
\mathrm{n}=70\end{array}$ & $\begin{array}{c}\text { P. norvegicus } \\
\mathrm{n}=37\end{array}$ & $\begin{array}{l}\text { M. tenuimana } \\
\mathrm{n}=139\end{array}$ \\
\hline Siphonophora (Chelophyes appendiculata) & 2.9 & - & 8.6 \\
\hline Glyceridae & - & 5.4 & - \\
\hline Unidentified polychaeta & 1.4 & 75.7 & 5.0 \\
\hline Acanthephyra pelagica & 24.3 & - & \\
\hline Pasiphaea multidentata & 7.1 & - & 5.0 \\
\hline Gennadas elegans & 1.4 & - & - \\
\hline Sergia robusta & 1.4 & - & - \\
\hline Decapoda Natantia & 2.9 & - & 2.9 \\
\hline Other Decapoda (Munida tenuimana) & - & - & 2.2 \\
\hline Euphausiacea (Meganyctiphanes norvegica) & 2.9 & - & 46.0 \\
\hline Hyperiidea & 18.6 & - & 4.3 \\
\hline Gammaridea & - & 2.7 & - \\
\hline Tanaidacea (Apseudes sp.) & - & 5.4 & - \\
\hline Unidentified crustacea & 12.9 & - & 3.6 \\
\hline Fish remains & 22.9 & - & 19.4 \\
\hline Gelatinous remains & 300 & - & 6.5 \\
\hline Unidentrfied debris (detritus, mud, etc.) & 11.4 & 8.1 & 5.0 \\
\hline
\end{tabular}

polychaetes and bivalves. Suprabenthos was the second food group in terms of biomass $(35.2 \%)$, with isopods such as Natatolana borealis and Munnopsurus atlanticus, large amphipods (basically Lysianassidae, Eusiridae, and Oedicerotidae), the mysid Boreomysis arctica and cumaceans as the most representative prey items. Macroplankton food resources were clearly secondary (only $10.0 \%$ ) and were mainly represented by the euphausiid Meganyctiphanes norvegica and mesopelagic fishes (Myctophidae, Cyclothone spp.). Megafaunal remains (pieces of large decapods, fishes or cephalopods) contributed $8.9 \%$ of the prey items of middle-slope dominant decapods and unidentified material $(1.9 \%)$ completed the diet at this depth level.

On the lower slope, benthic resources were also dominant $(32.7 \%$ of total weight), together with macroplankton prey $(30.4 \%)$ and suprabenthos $(21.8 \%)$. Benthic prey were represented here by polychaetes, bivalves and large foraminiferans, macroplankton were represented by Meganyctiphanes norvegica and, secondarily, by the shrimp Acanthephyra pelagica, while the suprabenthos was represented by the same groups cited for the middle slope, except the large isopod Natatolana borealis. Both megafaunal remains $(6.5 \%)$ and unidentified material $(9.1 \%)$ were secondary food sources.

\section{Daily rations of fish and annual food consumption}

For fish we adopted a mean daily ration of $0.611 \%$ WW/WW, deduced from values in Table 4 . The mean biomass values for the middle-slope assemblages were
$1221.6 \mathrm{~g} W W$ per $10000 \mathrm{~m}^{2}$ (RETRO cruises), and $1562.7 \mathrm{~g}$ WW per $10000 \mathrm{~m}^{2}$ (GEOS cruises). Combining the daily ration estimates and the biomass estimates, we calculated the annual food consumption during the 2 cruises as 7.463 and $9.548 \mathrm{~g}$ WW per $10000 \mathrm{~m}^{2} \mathrm{~d}^{-1}$ respectively. Annual food consumption in dry weight (using a DW/WW ratio of 0.25 ) was between 68.2 and $87.1 \mathrm{mg} \mathrm{DW} \mathrm{m} \mathrm{m}^{-2} \mathrm{yr}^{-1}$. Obviously, these estimates are less precise than the estimates for decapods and are employed here solely for comparative purposes.

\section{Production data and biomass of prey taxa}

We obtained direct and indirect data on macroplankton-macrofauna production. The taxa that we considered here are those well represented in the diet of megabenthic fish and decapods, as deduced from studies of stomach contents (Macpherson 1977, 1981, Carrasson et al. 1992). We do not include here taxa which are merely dominant in abundance, such as copepods, because of their small size and their small contribution to the diet of benthopelagic megafauna on the middle slope.

Sardou et al. (1996), for the northwestern Mediterranean area, gave a mean annual density value for Meganyctiphanes norvegica of 130 ind per $100 \mathrm{~m}^{2}$, integrating the water column between $800 \mathrm{~m}$ depth and the surface. We deduced a mean annual biomass of $156 \mathrm{mg}$ WW $\mathrm{m}^{-2}$, considering the specimens captured to have a wet weight of $0.12 \mathrm{~g}$ (based on the annual mean given in Franqueville 1971). Applying a 
Table 4. Daily ration (DR) of bathyal-benthopelagic and mesopelagic fishes considered to estimate a mean daily ration for fish assemblages on the middle-slope zone of the Catalan Sea. T: temperature. Data source: (1) Macpherson (1985); (2) Childress et al. (1980), combining data deduced from metabolic rates of 2 species, Lampanyctus ritteri (DR 0.87) and Lampanyctus regalis (DR 0.68); (3) Bulman \& Koslow (1992); (4) Koslow (1996). -: no temperature data in the original source

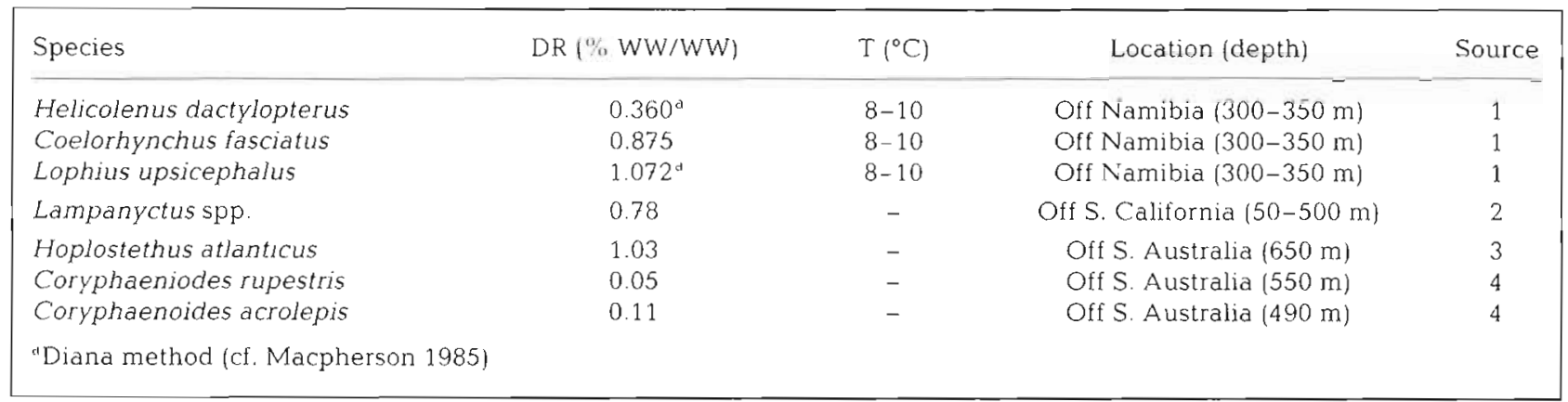

P/B of 1.24 (Labat et al. 1996) and a DW/WW ratio of 0.20 (authors' unpubl. data) we obtained a production of $38.7 \mathrm{mg} \mathrm{DW} \mathrm{m}^{-2} \mathrm{yr}^{-1}$. If we apply a $\mathrm{P} / \mathrm{B}$ ratio of 1.6 , as proposed by Mauchline (1985), production reached $49.9 \mathrm{mg} \mathrm{DW} \mathrm{m} \mathrm{m}^{-2} \mathrm{yr}^{-1}$ for this species. For the other smaller euphausiids dominant in our area we obtained a $P$ of $24.3 \mathrm{mg} \mathrm{DW} \mathrm{m} \mathrm{m}^{-2} \mathrm{yr}^{-1}$ (mean annual density = 75.2 ind. per $100 \mathrm{~m}^{2}$, Sardou et al. 1996; mean wet weight $=0.034 \mathrm{~g}$, authors' unpubl. data; mean $\mathrm{P} / \mathrm{B}=$ 4.75, Lindley 1982, Mauchline 1985). Euphausiids, which represent $\sim 1 / 3$ of total macroplankton abundance in the study area, have a total production of 63.0 to $74.2 \mathrm{mg} \mathrm{DW} \mathrm{m}^{-2} \mathrm{yr}^{-1}$ on the middle slope.

For peracarid communities we obtained a mean

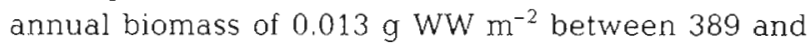
$1255 \mathrm{~m}$ which increased on the middle slope to $0.023 \mathrm{~g}$ WW $\mathrm{m}^{-2}$ This value, obtained by direct weighing after blotting, is probably an underestimate due to the fragility of most of these organisms, especially mysids, which appear broken in the samples. Despite this, considering the mean deduced $P / B$ of 8.05 , we estimated peracarid annual production at $26.2 \mathrm{mg} \mathrm{DW} \mathrm{m}^{-2} \mathrm{yr}^{-1}$ along the whole slope $46.3 \mathrm{mg} D W \mathrm{~m}^{-2} \mathrm{yr}^{-1}$ on the middle slope, 549 to $601 \mathrm{~m})$. Other suprabenthic groups in bathyal communities of the Catalan Sea comprised essentially small decapods (Processidae, Pandalidae and Crangonidae) which represented around $25 \%$ of the total biomass for these communities on the middle slope (from Macer-GIROQ samplings).

Finally, our estimate of polychaete production was based on a biomass value of $0.027 \mathrm{~g} \mathrm{DW} \mathrm{m}^{-2}$ (from the 400 to $1000 \mathrm{~m}$ depth interval in the south Aegean Sea; Tselepides \& Eleftheriou 1992) and a P/B ratio of 1.83 . The annual production of polychaetes was thus $49.4 \mathrm{mg} \mathrm{DW} \mathrm{m} \mathrm{m}^{-2} \mathrm{yr}^{-1}$. This approach probably underestimates the real value of polychaete production in the Catalan Sea, considering the oligotrophic characteristics of the south Aegean Sea (Tselepides \& Eleftheriou 1992). However, the polychaete biomass re- ported on the Catalan Sea shelf $10.337 \mathrm{~g} \mathrm{DW} \mathrm{m}^{-2}$ between 87 and $91 \mathrm{~m}$ depth; Guille 1971) was of the same order of magnitude as that reported by Tselepides \& Eleftheriou (1992) for the deeper 200 to $300 \mathrm{~m}$ interval $\left(0.164 \mathrm{~g} \mathrm{DW} \mathrm{m}^{-2}\right)$, suggesting that the 2 areas probably do not differ substantially in their infauna biomass values. Polychaete assemblages constituted $58 \%$ of total macrofauna sampled with grabs in the bathyal mud communities in the Catalan Sea (Reyss 1971).

\section{DISCUSSION}

In the Catalan Sea area, total food consumption by bathyal decapod assemblages was higher on the middle slope than on the lower slope at around $1200 \mathrm{~m}$. This must be mainly due to a decrease of megafaunal decapod biomass at those depths (Cartes \& Sardà 1993. Sardì et al. 1994), because, at a species level, those decapods dwelling at $1200 \mathrm{~m}$ did not show lower daily ration values. The decrease in food consumption by decapod assemblages with depth is also consistent with a general decrease in food availability: from suprabenthos, one of the main food sources of decapods, to infaunal species, such as Calocaris macandreae, or mesopelagic decapods and euphausiids, different prey taxa decrease in abundance with depth (Carpine 1970, Cartes 1998) along the northwestern Mediterranean slope. Considering this decrease in food availability, it would be expected that species inhabiting deeper levels would show lower daily rations, coinciding with results reporting a significant linear decrease in stomach fullness with depth (Cartes 1998) for Catalan Sea decapods. To explain this apparent inconsistency, the special characteristics of the 1200 to $1300 \mathrm{~m}$ depth stratum can be invoked. Some species (i.e. Munida tenuimana and Pontophilus norvegicus) showed maxima in mean size over this 


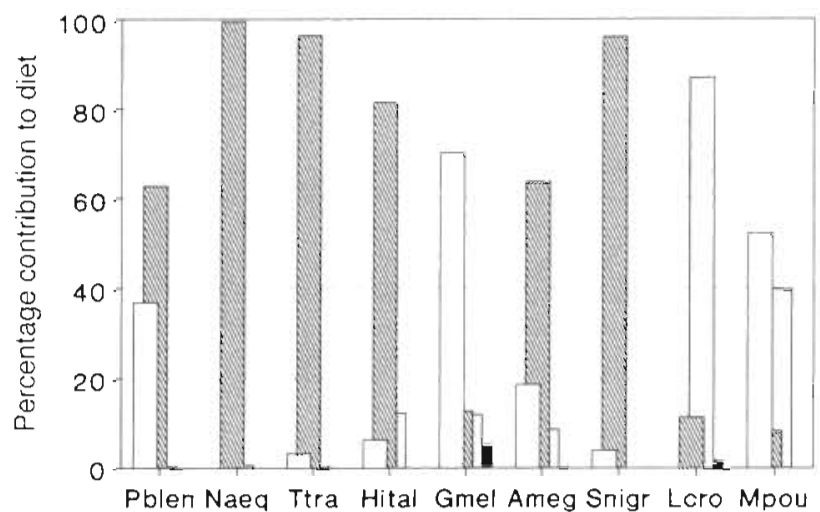

Fig. 4. Percentage contribution of the main food categorles to the diet of the dominant fish in the middle-slope assemblages of the Catalan Sea. ( $\square$ ) Megafauna + micronekton; ( $\mathrm{m}$ ) macrobenthos (benthos + suprabenthos) $(\square$ ) macroplanktoni (-) other (including unidentified items). In decreasing order of abundance: Pblen: Phycis blennoides; Naeq: Nezumia aequalis; Ttra: Trachyrhynchus trachyrhynchus; Hital: $H y-$ menocephalus italicus; Gmel: Galeus melastomus; Ameg Antonogadus megalokynodon; Snigr: Symphurus nigrescens; Lcro: Lampanyctus crocodilus; Mpout: Micromesistius poutassou. Data sources: Carrasson et al. (1992), Macpherson (1977, 1981), Stefanescu \& Cartes (1992)

depth interval, while a fish-biomass peak occurred at around $1200 \mathrm{~m}$ (Stefanescu et al. 1993, 1994). This suggests that at this depth stratum a secondary peak of production occurs, within the general decrease of biomass with depth. The flux derived from the DCM (deep chlorophyll maximum) detected in oceanic waters (Estrada 1991) over the lower slope may contribute to this local trend affecting biomass and size structure distributions in megafauna. Estimates of daily ration for the lower slope (below $1300 \mathrm{~m}$ ) would be of great interest in addressing this question.

Over the middle slope, fish communities are dominated by relatively small species, such as macrourids and Phycis blennoides (Sardà et al. 1994, Stefanescu et al. 1994). Dominant species on the middle slope base their diets on macrofauna and macroplankton, and only large specimens of $P$. blennoides and some secondary species such as sharks and Micromesistius poutassou also prey on megafaunal decapods, cephalopods and other fishes (Fig. 4). The small contribution of pelagic resources to fish diet (Fig. 4) applies only to the middle slope, not to deeper slope levels.

On the Catalan Sea lower slope, pelagic and benthopelagic prey increase their contribution to fish food requirements (Carrasson 1994), in accordance with the general trend described for other deep-sea fish assemblages (cf. Gordon \& Mauchline 1990). On the middle slope, decapods and fishes represent practically the entire megafaunal biomass, while other macrobenthos-macroplankton consumers, such as cephalopods or even some echinoderms, such as Astropecten irregularis, are comparatively scarce (Carpine 1970, Reyss 1971, Sardà et al. 1994). On the basis of the results from our study, we can conclude that total food consumption by this community should be close to the $160 \mathrm{mg}$ DW m $\mathrm{m}^{-2} \mathrm{yr}^{-1}$ calculated for decapods and fish, and also that the major part of this food is supplied by macroplankton and macrobenthic organisms (Fig. 4) Production by benthic and suprabenthic macrofauna was estimated at $-95 \mathrm{mg} \mathrm{DW} \mathrm{m} \mathrm{m}^{-2} \mathrm{yr}^{-1}$ considering only the 2 dominant taxa (polychaetes and peracarid crustaceans) in our area. Both groups comprise nearly $2 / 3$ of the total benthos, and total production by benthos can be roughly estimated at $150 \mathrm{mg}$ DW $\mathrm{m}^{-2} \mathrm{yr}^{-1}$, in close agreement with the biomass consumed by megafaunal communities.

As deduced from stomach data, the contribution of macroplankton to this scheme is secondary. Considering our data from summer (cruise DN-1), only $10 \%$ of the stomach content weight is of macroplankton origin. However, macroplankton consumption by bathyal organisms in the northwestern Mediterranean follows a seasonal pattern. Euphausiids become seasonally important in the diet of decapods in September-October and also in spring (Cartes 1991), approximately coinciding with vertical or ontogenic migrations by Meganyctiphanes norvegica to deep waters in the study area (Sardou et al. 1996). An annual estimated volume (Cartes 1991), covering all seasons, increases the total volume of macroplanktonic food consumed by decapods to $\sim 20 \%$, of which euphausiids constitute $\sim 45 \%$ (9\% of total). This $9 \%$ euphausiid portion of total food consumed by decapods $\left(\sim 7.3 \mathrm{mg} \mathrm{DW} \mathrm{m}^{2} \mathrm{yr}^{-1}\right)$ represents $10.6 \%$ of euphausid production. Euphausiids, as part of the macroplankton, are only preyed upon by some secondary fishes in middle-slope communities, such as Lampanyctus crocodilus and the blue whiting Micromesistius poutassou (Macpherson 1977 , 1981, Stefanescu \& Cartes 1992) (see Fig. 4). The contribution of euphausiids to food supply seems lower for mid-slope fish than that deduced for decapods, and thus the percentage of euphausiid production consumed by our mid-bathyal communities hardly attains $20 \%$. This contribution, although lower than that estimated for Antarctic krill Euphausia superba $139 \%$ of the yearly krill production is consumed by Antarctic demersal fish; Pakhomov 1997), still can be significant for deep-water communities.

Our results on food supply and food consumption suggest the existence of a delicate balance in the bathyal community studied, adding evidence to the commonly accepted idea of food supply being the main limiting factor in deep-sea trophic webs (Gage \& Tyler 1991). In the NW Mediterranean, all macrobenthic and macroplanktonic production is apparently consumed 
by megafauna, as is usually assumed in models of C flux in trophic webs (Huntley et al. 1991). Fish and decapods showed similar levels of food consumption, and our results point to a $50 \%$ share of each of these taxa in the consumption of macroplankton-macrobenthos production. The $-50 \%$ of production exploited by our benthopelagic fish community would be within the range of ca 40 to $76 \%$ of annual secondary production consumed by mesopelagic fish reported by Huntley et al. (1991) and Pakhomov et al. (1996) in the Southern Ocean and Antarctic waters.

Comparing the food consumption calculated for decapods and the value deduced for fishes, similar levels of annual food consumption for both dominant megafaunal groups were obtained on the middle slope, despite the fact that fish biomass was $\sim 1.7$ times higher than decapod biomass in the same samplings (Cartes et al. 1994a). At this level, decapods annually consume 3.09 times their mean biomass (in dry weight), while demersal fish consume 2.23 times theirs. These values are below the value of $600 \%$ of fish body weight estimated for mesopelagic fish (Naumov 1985, in Pakhomov et al. 1996) in the Southern Ocean, suggesting benthopelagic bathyal communities are more efficient than midwater ones, although here we are comparing different areas with different estimates of biomass (at a bathymetric level in our case and over an extensive area in the Antarctic studies). Unfortunately, $P$ and $P / B$ values for megafaunal bathyal species are not available, and comparisons between the efficiencies of different taxa are not possible yet. Assuming similar levels of $P$ for fish and decapods in our area, one could speculate that fish are more efficient than decapod crustaceans on the middle slope.

In any case, the benthos is the main contributor to food supply in our bathyal megafaunal communities on the middle slope, coinciding with other trophic webs in shallow waters of subarctic and temperate areas (Steele 1974, Mills 1975, Petersen \& Curtis 1980). Furthermore, in the NW Mediterranean, suprabenthic production (traditionally ignored in other studies) increases the importance of benthos compared to zooplankton in terms of food supply.

Advective inputs of organic matter to the seabed have been reported at 1 to $10 \mathrm{~g} \mathrm{C} \mathrm{m}^{-2} \mathrm{yr}^{-1}$ (Buscail et al. 1990), depending on the method used, in the adjacent slope of the Lacaze-Duthier Canyon in the northern Catalan Sea. These values are probably a high estimate for our open-slope station (interfluve) on the middle slope, due to the fact that organic $C$ in surface sediments is lower in the open slope between canyons than in canyons (Buscail et al. 1990). Between 49 and $60 \%$ of this flux is consumed by benthic organisms while the rest is buried, i.e. not immediately consumed (Buscail et al. 1990). According to these authors, the proportion of $\mathrm{C}$ would amount to 0.6 to $4.9 \mathrm{~g} \mathrm{C} \mathrm{m}^{-2} \mathrm{yr}^{-1}$. A mean value of $2.75 \mathrm{~g} \mathrm{C} \mathrm{m}^{-2} \mathrm{yr}^{-1}$ with a canyon/interfluve ratio of 1.5 for organic $C$ in sediments (cf. Buscail et al. 1990) gives an estimate of $1.83 \mathrm{~g} \mathrm{C} \mathrm{m}^{-2} \mathrm{yr}^{-1}$ that we can adopt for our study area. Macrobenthos can consume this C either directly (e.g. Boreomysis arctica; authors unpubl. data) or via meiofauna (foraminiferans, harpacticoideans). Foraminiferans, for instance, which accumulate a high benthic biomass, consume mainly planktonic and other detritus (Gooday 1988), while they are preyed upon by suprabenthic isopods (Svavarsson et al. 1993) and amphipods (authors' unpubl. data). The efficiency with which this production is transferred up through food chains, called ecological efficiency, is regularly assumed to be $10 \%$ (Lindeman 1941), although, in one study of benthic marine food chains, Steele (1974) obtained efficiencies of 23 to $25 \%$ for macro- and meiobenthos. This would represent between 0.018 and $0.183 \mathrm{~g} \mathrm{C} \mathrm{m}^{-2} \mathrm{yr}^{-1}$ (efficiency $=$ $10 \%$ ) or between 0.105 and $0.421 \mathrm{~g} \mathrm{C} \mathrm{m}^{-2} \mathrm{yr}^{-1}$ (following Steele's estimations) being available to megafaunal communities at 600 to $710 \mathrm{~m}$ depth, depending on whether consumption is direct or occurs via meiofauna by infauna and suprabenthos. The role of bacteria in this food input could be particularly important in the deep Mediterranean due to the relatively high temperature $\left(13^{\circ} \mathrm{C}\right)$ in the water column below $200 \mathrm{~m}$. Their dominance in the deep-sea benthos (Pfannkuche 1992) and their degradation activity must add another step in food webs, reducing the amount of $C$ supply available for megafauna and upper food chains. Our estimation of food consumption for middle-slope megafaunal communities is, based on DW calculations, $0.059 \mathrm{~g} \mathrm{C}$ $\mathrm{m}^{-2} \mathrm{yr}^{-1}$, closely matching the supply of $\mathrm{C}$ deduced from flux data. Assuming that this value is close to the food supply (production) by benthos, and adopting the values mentioned above for ecological efficiency (10 to $23 \%)$, macrobenthic communities would consume between 0.6 and $0.26 \mathrm{~g} \mathrm{C} \mathrm{m}^{-2} \mathrm{yr}^{-1}$, which is less than $1 \%$ of annual primary production (mean value between 77 and $100 \mathrm{~g} \mathrm{C} \mathrm{m}^{-2} \mathrm{Yr}^{-1}$; Miquel et al. 1994) in the western Mediterranean.

In a comparative study of shallow-water communities, Petersen \& Curtis (1980) linked the ratio of zooplankton/benthos (excluding suprabenthos) production to a latitudinal gradient. This ratio was $6: 1$ in a tropical ecosystem and 3:1 in a temperate area, and decreased to $1: 1$ in subarctic systems. This is also in agreement with a general decrease of deep-sea benthos biomass from high to low latitudes (Rowe 1983). In our results from the dominant taxa in the macroplankton (euphausiids) and benthos (polychaetes), this ratio is closer to $1: 1$. Considering the high and similar proportion of these taxa in their respective compartments, one can extrapolate this ratio to the entire macroplank- 
ton-benthos (suprabenthos excluded). Thus, despite the fact that our study area is located in a temperatesubtropical zone, its bathyal trophic webs are more closely related to subarctic areas in terms of zooplankton/benthos production. This suggests that an increase in depth could have a similar influence on trophic web structure to a latitudinal increase. A common origin for both polar and deep-sea fauna has already been proposed (Lipps \& Hickman 1982). There are some species common to both Mediterranean and Atlantic faunas, presenting a bathyal distribution in the Mediterranean and occupying shallow waters in North Atlantic boreal waters (Carpine 1970). At our ecological level, the macroplankton-benthos production balance seems to agree well with these faunistic and biogeographic considerations. Suprabenthos, which can constitute an important part of benthic production in our system, has traditionally been ignored in other balances. The zooplankton-benthos ratio is also related to the development of demersal or pelagic fisheries in a concrete area (Petersen \& Curtis 1980). Thus, while demersal fish are important in subarctic ecosystems, they are comparatively unimportant in the tropics. Deep-water fisheries in our slope area are exclusively directed at demersal species, especially shrimps (Bas et al. 1985), adding some evidence to the scheme proposed by Petersen \& Curtis.

Acknowledgements. We thank Dr S. Tudela for critical reading of the manuscript and the people in the cruises DN and BT-1, especially Dr F. Sardà, for field assistance during the survey. This study was funded by the 'Consejo Superior de Investigaciones Científicas' (Spanish government) and by CICYT (Comisión Interministerial de Ciencia y TecnologíaMinistry of Research and Science).

\section{LITERATURE CITED}

Bas C, Macpherson E, Sarda F (1985) Fishes and fishermen. The exploitable trophic levels. In: Margalef $\mathrm{R}$ (ed) Key environments: western Mediterranean. Pergamon Press, New York, p 296-316

Bergstad OA (1990) Ecology of the fishes of the Norwegian Deep: distribution and species assemblages. Neth J Sea Res 25:237-266

Bosclair D, Leggett WC (1988) An in situ experimental evaluation of the Elliot and Persson and the Eggers models for estimating fish daily ration. Can J Fish Aquat Sci 45 $138-145$

Brey T (1990) Estimating productivity of macrobenthos invertebrates from biomass and mean individual weight. Meeresforschung 32:329-343

Bromley PJ (1994) The role of gastric evacuation experiments in quantifying the feeding rates of predatory fish. Rev Fish Biol Fish 4:36-66

Buchanan JB, Warwick RM (1974) An estimate of benthic macrofaunal production in the offshore mud of the Northcumberland coast. J Mar Biol Assoc UK 54:197-222

Bulman CM, Koslow JA (1992) Diet and food consumption of a deep-sea fish, orange roughy Hoplostethus atlanticus
(Pisces: Trachichthydae), off southeastern Australia. Mar Ecol Prog Ser 82:115-129

Buscail R, Pocklington R, Daumas R, Guidi L (1990) Fluxes and budget of organic matter in the Benthic Boundary Layer over the northwestern Mediterranean. Cont Shelf Res 10:1089-1122

Carpine C (1970) Ecologie de l'étage bathyal dans la Méditerranée occidentale. Mem Inst Oceanogr Monaco 2:1-146

Carrasson M (1994) Relaciones tróficas en las comunidades ícticas bentónicas (de 1000 a $2200 \mathrm{~m}$ ) del Mar Catalán. Tesis doctoral, Univ Autónoma de Barcelona

Carrasson M, Stefanescu C, Cartes JE (1992) Diet and bathymetric distribution of two bathyal sharks of the Catalonian deep sea. Mar Ecol Prog Ser 82:21-30

Cartes JE (1991) Análisis de las comunidades y estructura trófica de los crustáceos decápodos batiales del Mar Catalán. Tesis doctoral, Univ Politecnica de Catalunya

Cartes JE (1993) Day-night feeding by decapod crustaceans in a deep-water bottom community in the western Mediterranean. J Mar Biol Assoc UK 73:795-811

Cartes JE (1994) Influence of depth and season on the diet of the deep-water aristeid Aristeus antennatus along the continental slope (between 400 to $2300 \mathrm{~m}$ ) in the Catalan Sea (western Mediterranean). Mar Biol 120:639-648

Cartes JE (1998) Feeding strategies and partition of food resources in deep-water decapod crustaceans in relation to depth (between 400-2300 m). J Mar Biol Assoc UK (in press)

Cartes JE, Company JB, Maynou F (1994a) Deep-water decapod crustaceans communities in the northwestern Mediterranean: influence of submarine canyons and season. Mar Biol 120:221-230

Cartes JE, Sarda F (1992) Abundance and diversity of decapod crustaceans in the deep Catalan Sea (western Mediterranean). J Nat Hist 26:1305-1323

Cartes JE, Sarda F (1.993) Zonation of the deep-sea decapod fauna in the Catalan Sea (western Mediterranean). Mar Ecol Prog Ser 94:27-34

Cartes JE, Sorbe JC (1995) Deep-water mysids of the Catalan Sea: species compostion, bathymetric and near bottom distribution. Mar Biol Assoc UK 75:187-197

Cartes JE, Sorbe JC (1996) Temporal population structure in deep-water cumaceans along the western Mediterranean slope (between 400 to $1300 \mathrm{~m}$ ). Deep-Sea Res 43 $1423-1438$

Cartes JE, Sorbe JC, Sardà F (1994b) Spatıal distribution and swimming activity of deep-sea decapods and euphausiids near the bottom in the northwestern Mediterranean. J Exp Mar Biol Ecol 179:131-144

Childress JJ, Taylor SM, Cailliet CM, Price MH (1980) Patterns of growth, energy utilization and reproduction in some meso- and bathypelagic fishes off Southern California. Mar Biol 61:27-40

Clarke TA (1978) Diel feeding patterns of 16 specles of mesopelagic fishes from Hawaiian waters. Fish Bull US 76: $495-513$

Durbin EG, Durbin AG, Langton RW, Bowman RE (1983) Stomach contents of silver hake, Merluccius bilineans, and Atlantic cod, Gadus morhua, and estimation of their daily rations. Fish Bull US 81(3):437-454

Eggers DM (1977) Factors in interpreting data obtamed by diel sampling of fish stomachs. J Fish Res Bd Can 34: $290-294$

Eggers DM (1979) Comments on some recent methods for estimating food consumption by fish. J Fish Res Bd Can 36 : $1018-1019$

Efliott JM, Persson L (1978) The estimation of daily rates of 
food consumption for fish. J Anim Ecol 47:977-991

Estrada M (1991) Phytoplankton assemblages across a NW Mediterranean front: changes from winter to spring stratification. Oecol Aquat 10:157-185

Franqueville C (1971) Macroplancton profond (lnvertebrés) de la Méditerranéee nord-occidentale. Tethys 3:11-56

Gage JD (1992) Benthic secondary production in the Deep Sea. In: Rowe GT, Pariente V (eds) Deep-sea food chains and the global carbon cycle. Kluwer Academic Publishers, Dordrecht, p 199-216

Gage JD, Tyler PA (1991) Deep-sea bıology. Cambridge University Press, Cambridge

Gooday AJ (1988) A response by benthic foraminifera to the deposition of phytodetritus in the deep sea. Nature 332 : $70-73$

Gordon JDM, Mauchline J (1990) Depth-related trends in diet of a deep-sea bottom-living fish assemblage of the Rockall Trough. In: Barnes M Gibson RN (eds) Trophic relationships in the marine environment. Proc 24th Eur Mar Biol Symp. Aberdeen Univ Press, Aberdeen, p 439-452

Gulle A (1971) Bionomie benthique du plateau continental de la côte catalane française. IV-densités, biomasses et variations saisonnières de la macrofaune. Vie Milieu 22 . $93-118$

Haedrich RL, Merrett N (1992) Production/biomass ratios, size frequencies and biomass spectra in deep-sea demersal fishes. In: Rowe GT, Pariente $V$ (eds) Deep-sea food chains and the global carbon cycle. Kluwer Academic Publishers, Dordrecht, p 157-182

Hopkins TS (1985) Physics of the sea. In: Margalef R (ed) Key environments: western Mediterranean. Pergamon Press, New York, p 100-125

Huntley ME, Lopez MDG, Karl DM (1991) Top predators in the Southern Ocean: a major leak in the biological carbon pump. Science 253:64-66

Jones R (1978) Further observations on the energy flow to the major fish species in the North Sea. ICES CM 1978/Gen: 6 (Symp)

Jorgensen SE, Nielsen SN, Jorgensen LA (1991) Handbook of ecological parameters and ecotoxicology. Elsevier Science Publishers, Amsterdam

Koslow JA (1996) Energetic and lufe-history patterns of deepsea benthic, benthopelagic and seamount-associated fish. $J$ Fish Biol 49(A):54-74

Labat JP, Couzin-Roudy J (1996) Population dynamics of the kryll Meganyctiphanes norvegica (M. Sars, 1857) (Crustacea: Euphausiacea) in the Ligurian Sea (NW Mediterranean Sea). Size structure, growth and mortality modelling. J Plankton Res 18(12):2295-2312

Lindeman RL (1941) Food cycle dynamics un a senescent lake Am Midl Nat 32:636-673

Lindley JA (1982) Population dynamics and production of euphausiids. IIl. Meganyctiphanes norvegica and $\mathrm{Nyc}$ tiphanes couchii in the North Atlantic Ocean and the North Sea. Mar Biol 66:37-46

Lipps JH, Hickman CS (1982) Origin, age, and evolution of antarctic and deep-sea faunas. In: Ernst WG, Morin VG (eds) The environment of the deep-sea. Prentice Hall, New Jersey, p 324-356

Macpherson E (1977) Estudio sobre relaciones troficas en peces bentónicos de la costa catalana. Tesis doctoral, Universidad de Barcelona

Macpherson E (1981) Resource partitioning in a Mediterranean demersal fish community. Mar Ecol Prog Ser 4 : $183-193$

Macpherson E (1985) Dally ration and feeding periodıcity of some fishes off the coast of Namibia. Mar Ecol Prog Ser 26
$253-260$

Mauchline J (1985) Growth and production of Euphausiacea (Crustacea) in the Rockall Trough. Mar Biol 90:19-26

May JL, Blaber SJM (1989) Benthic and pelagic fish biomass of the upper continental slope off eastern Tasmania. Mar Biol 101:11-25

Maynou F, Cartes JE (1997) Field estimation of daily ration in deep-sea shrimp Aristeus antennatus (Crustacea: Decapoda) in the western Mediturranean. Mar Ecol Prog Ser 153:191-196

Maynou F, Cartes JE (1998) Daily ration estimates and comparative study of food consumption in nine species of deep-water decapod crustaceans of the $\mathrm{N} W \mathrm{M}$ Mediterranean. Mar Ecol Prog Ser 171:221-231

Maynou F, Conan GY, Cartes JE, Company JB (1996) Spatial structure and seasonality of decapod crustacean populations on the Northwestern Mediterranean slope. Limnol Oceanogr 41(1): 113-125

Mills EL (1975) Benthic organisms and the structure of marine ecosystems. J Fish Res Bd Can 32(9):1657-1663

Miquel JC, Fowler SW, La Rosa J, Buat-Menard P (1994) Dynamics of the downward flux of particle and carbon in the open northwestern Mediterranean. Deep-Sea Res 41 : 243-261

Morin A, Bourassa N (1992) Mòdeles empiriques de la production annuelle et du rapport $P / B$ d'invertébrés benthiques d'eau courante. Can J Fish Aquat Sci 49:532-539

Naumov AG (1985) System analysis of the structure of the Antarctic waters community. In: Vinogradov ME, Flint MV [eds] Biological basis of the commercial utilization of the open regions of the ocean. Nauka Press, Moscow, p 57-80 (in Russian)

Pakhomov lis (1997) Feeding and exploitation of the food supply by demersal fishes in the Antarctic part of the [ndian Ocean. J Ichthyol 37:360-380

Pakhomov EA, Perissinotto R, McQuaid CD (1996) Prey composition and daily rations of myctophid fishes in the Southern Ocean. Mar Ecol Prog Ser 134:1-14

Petersen GH, Curtis MA (1980) Differences in energy flow through major components of subarctic, temperate and tropical marine shelf ecosystems. Dana 1:53-64

Pfannkuche $O$ (1992) Organic carbon flux through the benthic community in the temperate abyssal northeast Atlantic. In: Rowe GT, Pariente $V$ (eds) Deep-sea food chains and the global carbon cycle. Kluwer Academic Publishers, Dordrecht, p 183-198

Reyss D (1971) Les canyons sous-marins de la Mer Catalane, Le Rech du Cap et le rech Lacaze-Duthiers. III-Les peuplements de macrofaune benthique. Vie Milieu 22:529-613

Rosenberg R, Olsson I. Olundh E (1977) Energy flow model of an oxygen-deficient estuary on the swedish west coast. Mar Biol 42:99-107

Rowe GT (1983) Biomass and production of the deep-sea macrobenthos. In: Rowe GT (ed) Deep-sea biology: the sea, Vol 8. John Wiley \& Sons, New York, p 97-121

Sardà F, Cartes JE, Company JB (1994) Spatio-temporal variation in megabethos abundance in three different habitats of the Catalan deep-sea (Western Mediterranean). Mar Biol 120:211-221

Sardà F, Valladares FJ (1990) Gastric evacuation of different foods by Nephrops norvegicus (Crustacea: Decapoda) and estimation of soft tissue ingested, maximum food intake and cannubalism in captivity. Mar Biol 104:25-30

Sardou J, Etienne M. Andersen V (1996) Seasonal abundance and vertical distributions of macroplancton and micronecton in the northwestern Mediterranean. Oceanol Acta 19: 645-656 
Steele JH (1974) The structure of marine ecosystems. Blackwell Scientific Publications, Oxford

Stefanescu C, Cartes JE (1992) Benthopelagic habits of adult specimens of Lampanyctus crocodilus (Risso, 1810) (Osteichthyes. Myctophidae) in the Western Mediterranean deep slope. Sci Mar 56(1):69-74

Stefanescu C, Lloris D, Rucabado J (1993) Deep-sea fish assemblages in the Catalan Sea (western Mediterranean) below a depth of $1000 \mathrm{~m}$. Deep-Sea Res 40:695-707

Stefanescu C, Morales- $M$ in B, Massutí E (1994) Fish assemblages on the slope in the Catalan Sea (western Mediterranean\}: influence of a submarine canyon. J Mar Biol Assoc UK 74:499-512

Svavarsson J, Gudmundsson G, Brattegard T (1993) Feeding by asellote isopods (Crustacea) on foraminifers (Protozoa)

Editorial responsibility: Otto Kinne (Editor),

Oldendorf/Luhe, Germany in the deep sea. Deep-Sea Res 40:1225-1239

Swynnerton GH, Worthington EB (1940) Note on the food of fish in Haweswater (Westmorland). J Anim Ecol 9:183-187

Tselepides A, Eleftheriou A (1992) South Aegean (eastern Mediterranean| continental slope benthos: macroinfaunal-environmental relationships. In: Rowe GT, Pariente $\mathrm{V}$ (eds) Deep-sea food chains and the global carbon cycle. Kluwer Academic Publishers, Dordrecht, p 139-156

Worobec MN (1984) Field estimation of the daily ration of winter flounder, Pseudopleuronectes americanus (Walbaum) in a southern New England salt pond. J Exp Mar Biol Ecol 77:183-196

Yang MS, Livingston PA (1988) Food habits and daily rations of greenland halibut Rheinhardhus hippoglossoides in the eastern Bering Sea. Fish Bull NOAA 86(4):625-690

Submitted: February 24, 1998; Accepted: May 29, 1998 Proofs received from author(s): August 31, 1998 